\title{
MINERALOGY AND PETROLOGY OF KIMBERLITE DYKE AND SHEET INTRUSIONS IN SOUTH-WEST GREENLAND
}

\author{
C.H. Emeleus ${ }^{1}$ by ${ }^{1}$ and James R. Andrews ${ }^{2}$
}

1. Dept. of Geological Sciences, University of Durham, Durham, England. 2. Dept. of Geology, University College, Belfield, Dublin 4, Ireland.

Dykes and thin sheets of kimberlite intrude Precambrian rocks between Holsteinsborg and Ivigtut. At three localities, Nigerdlikasik $\left(62^{\circ} \mathrm{O} 2^{\prime} \mathrm{N}, 48^{\circ} 51^{\prime} \mathrm{W}\right)$, Midternaes $\left(61^{\circ} 33^{\prime} \mathrm{N}, 48^{\circ} 10^{\prime} \mathrm{W}\right)$ and Pyramidef jeld $\left(61^{\circ} 25^{\prime} \mathrm{N}, 48^{\circ} 15^{\prime} \mathrm{W}\right)$ a dyke and sheet complexes, dated at about 220 my., consists of fresh kimberlite with frequent peridotite nodules and sparser inclusions of crustal rocks. Modal analyses of the kimberlites show considerable variations (Andrews \& Emeleus 1971, Table 1) particularly in diopside, phlogopite and carbonate. The nodules are generally very olivine rich with lesser amounts of orthopyroxene, clinopyroxene and other minerals (ibid., Table 2). Whole rock analyses (8) from two of the localities show little variation, these analyses and trace element determinations on kimberlite from Nigerdlikasik give compositions closely comparable to a composite sample from the Benfontein kimberlite (Dawson \& Hawthorne 1973, Tables 2 \& 3; Hawthorne 1968).

The kimberlites contain olivine, chromite, titanomagnetite, perovskite, clinopyroxene, phlogopite, calcite, ferroan dolomite, and serpentine, which crystallised in approximately that order, together with minor apatite and amphibole. An earlier tentative identification of mellilite was not confirmed. Peridotite nodules consist of dominant olivine together with variable amounts of orthopyroxene, chrome diopside, garnet, chrome spinel and phlogopite. Textures are generally xenomorphic granular though idiomorphic and poikilitic crystals may also be present. Several dunite mylonite nodules and olivine-rich nodules with incipient granulation and crushing were found at Pyramidefjeld. The nodules are rounded, up to $200 \mathrm{~mm}$ in diameter and sharply defined against the kimberlite. There is little sign of reaction between nodules and kimberlite although penetration by kimberlite veins occurs and there may be serpentinisation of olivines in the nodules. Compositional data for selected minerals are given in the table (see page 4).

Olivines in the kimberlites are of variable compositions, examples with normal and with reversed zoning are present. The olivine habits also vary, several of the types distinguished at Benfontein may be recognised (Groups i, iii and iv, Dawson \& Hawthorne 1973, pp.66, 67). Peridotite olivines are remarkably constant in composition, the only major departure from ca. Fo9o was in the more iron rich olivines forming the larger, strained crystals in some dunite mylonites and crushed peridotites. The diopside in the kimberlite shows slight normal zoning. Nodule clinopyroxenes differ from those in the kimberlite, they are appreciably more magnesian, show a range of enstatite-diopside solid solution (largely within field 'A' of Boyd \& Nixon, 1973) and contain higher $\mathrm{Cr}$ and $\mathrm{Na}$. Chrome diopsides from phlogopite-, spinel-and garnet-peridotites are characterised by different amounts of $\mathrm{Al}, \mathrm{Ti}$ and $\mathrm{Cr}$. The chrome diopside usually occurs as discrete crystals but in the phlogopite peridotites it is 
also found intergrown with low-Al chromite and phlogopite. Orthopyroxene is restricted to peridotites. It is fairly constant in composition although variation in Al parallels that found in peridotite clinopyroxenes. Inclusions are uncommon in orthopyroxene, exsolution lamellae analysed in one sample are of chrome spinel, accompanied by (unanalysed) clinopyroxene lamellae. Garnet, chrome spinel and phlogopite are the principal aluminous phases in the peridotites and have been used to classify them. The garnet is a chrome pyrope. The crystals almost invariably show signs of instability, a prominent reaction $r i m$ is developed consisting of chrome spinel, orthopyroxene and minor chrome diopside. Phlogopite is frequently intimately associated with the reaction rims. Spinel of the spinel peridotites is a dark brown variety rich in $\mathrm{Mg}, \mathrm{Al}$ and $\mathrm{Cr}$, the nodules containing spinel are remarkably fresh and there is a complete absence of mica. Other spinels found in the peridotites include well-formed chromites in garnet and in chrome diopside. Opaque minerals in the kimberlites include chromite and titanomagnetite as composite grains, chromite may form the core to a crystal or both may be complexly intergrown. Phlogopite in the peridotites occurs as large well-formed crystals and intergrown with clinopyroxene and chromite. It is present in most nodules except the spinel peridotites and dunite mylonites. The kimberlite micas are zoned to colourless margins or to margins showing intense reversed pleochroism in deep red-brown to pale brown colours. (Al-poor tetraferriphlogopite, cf. Rimskaya-Korsakova \& Sokolova 1964). The peridotite and kimberlite phlogopites differ in the relatively high $\mathrm{Si}$ and $\mathrm{Mg}$ of the former, and the higher $A l$ and $F e$ of the latter. The latest minerals to crystallise from the kimberlite magma were phlogopite, carbonate (sometimes with clear calcite rims to ferroan-dolomite) and fine-grain serpentine of unusually iron-rich composition (up to $11.6 \%$ FeO). Late-stage veins, cross-cutting nodules and kimberlite, show the same crystallisation sequence, early marginal phlogopite is oriented approximately perpendicular to the vein edges, later carbonate develops good crystal faces towards the vein centre which is filled with fine-grain, pale green serpentine.

The kimberlite intruded as a low temperature magma with little effect on its surroundings apart from marginal shattering and extensive carbonation of siltstones on Midternaes. The zoned olivines and pyroxenes indicate differentiation prior to emplacement and/or crystallisation over a temperature range. The normal and reversed zoning of the olivines converges on a compositional band around Fo8884, the derivation of Fe-rich reversed zoned olivines from a crustal source is suggested by their association with fragments of crustal rock containing Fe-rich orthopyroxene. Forsteritic olivines may have originated as phenocrysts and/or through fragmentation of peridotite nodules. The absence of other xenocrysts (enstatite, chrome diopside, garnet) may be attributed to their low concentrations in the peridotites. The virtual absence of clinopyroxene in the Nigerdlikasik kimberlite and its presence elsewhere (up to 25 vol.\%) may be a reflection of silica variation. The general mineralogy of the kimberlites is similar to kimberlites from other areas, although the Greenland example appears remarkably fresh; however, the absence of picroilmenite is notable. The mineral analyses show the latest liquid in the kimberlite was depleted in Al almost to the extent of its elimination (cf. the tetraferriphlogopite rims and the absence of any Al phase with the 
last-crystallised serpentine) and somewhat Fe enriched (cf. the presence of tetraferriphlogopite and the serpentine compositions).

The garnet and spinel peridotites are considered to represent mantle material derived respectively from relatively deep and shallow levels. There is no sign of instability in minerals of the spinel peridotites but in the garnet peridotites the garnet is almost always altered. Phlogopite is often found closely associated with the reaction rims surrounding garnet; in some examples garnet has a thick reaction rim near phlogopite but little or no rim next to olivine or pyroxenes. In this situation the large phlogopites are also found to be corroded and replaced. The petrographic relations thus suggest a reaction involving primary garnet and phlogopite resulting in the formation of chrome spinel, orthopyroxene and chrome diopside, and the apparent elimination of $\mathrm{K}$ and $(\mathrm{OH})$ from the system. In this situation the phlogopite appears to be of primary, deep-seated origin. The majority of the phlogopite peridotites, found mainly in Pyramidefjeld, contain no garnet. However, some of the phlogopite occurs intergrown with other minerals, as described earlier. These intergrowths may represent the end product of alteration of an earlier aluminous phase (spinel, garnet) in the presence of potash and waterrich kimberlite magma; thus, some of the phlogopite kimberlites may have originated through reaction between mantle wall rock and active kimberlite magma, while other phlogopite-bearing peridotites appear to pre-date the kimberlite.

The distribution of minor elements between pyroxenes, the absence of reaction rims around nodules and where late veins cut kimberlites and peridotites, indicate that the peridotite assemblages equilibrated with their Al-rich phase (garnet, spinel or phlogopite) prior to emplacement at their present crustal levels.

Andrews, J.R. and Emeleus, C.H. 1971 Gronlands gөol.Unders.,Rapp 31.pp.

Boyd, F.R. and Nixon, P.H. 1972 Carnegie Inst.Yr.Bk, 71, 362-373. Dawson, J.B. and Hawthorne, J.B. $1973 \mathrm{Jl}$. geol.Soc.Lond., 129, 61-86.

Hawthorne, J.B. 1968 Trans.geol.Soc. S. Afr, 71, 291-311.

Rickwood, P.C. 1968 Contr. Mineral. and Petrol., 18, 175-198.

Rimskaya-Korsokova O.M. \& Sokølova, E.P. 1964 Zap.Vses.Min.Obshch. 93, 411-423. (also Mineral.Abs.17, 504, 1966)

For table see overleaf 


\section{Summary of mineral compositional ranges}

\section{Peridotites}

$\frac{\text { Olivine }}{\text { (atom } \%)}$

Orthopyroxene

Clinopyroxene

(atom \%)

Phlogopite

(wt.\%)

Mg $92.4-88.5$

$\frac{\mathrm{Mg}}{92.4} \quad \frac{\mathrm{Fe}}{6.6} \quad \frac{\mathrm{Ca}}{1.0}$

$\begin{array}{lll}89.5 & 9.8 & 0.7\end{array}$

$\frac{\mathrm{Mg}}{53.2} \quad \frac{\mathrm{Fe}}{3.4} \quad \frac{\mathrm{Ca}}{43.4}$

$47.0 \quad 4.3 \quad 48.7$
Mg $86.0-76.6$ (1)

$\mathrm{SiO} \quad 42.1 \quad 37.4$

$\mathrm{Al}_{2} \mathrm{O}_{3} 11.9 \quad 15.6$

$\mathrm{FeO}^{3} 3.8 \quad 5.4$

MgO $25.9 \quad 20.3$

$\frac{\mathrm{Mg}}{80.2} \frac{\mathrm{Fe}}{18.1} \frac{\mathrm{Ca}}{1.7}$

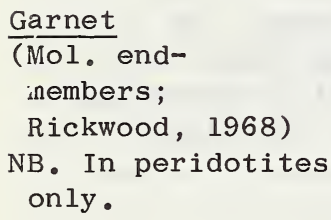

\section{Kimberlites}

Mg $92.4-75.7$ 